\title{
FORMATION OF THE SOCIAL AND ECONOMIC SECURITY MECHANISM OF THE REPUBLIC OF BELARUS
}

CShvaiba D., ORCID: 0000-0001-6783-9765; Ph.D., Belarusian Trade Union of workers of chemical, mining and oil industries; Belarusian national technical University,

Minsk,Belarus,shvabia@tut.by

\section{ФОРМИРОВАНИЕ МЕХАНИЗМА ОБЕСПЕЧЕНИЯ СОЦИАЛЬНО- ЭКОНОМИЧЕСКОЙ БЕЗОПАСНОСТИ РЕСПУБЛИКИ БЕЛАРУСЬ}

\begin{abstract}
СШвайба Д. Н., ORCID: 0000-0001-6783-9765; канд. экон. наук, Белорусский профсоюз работников химической, горной и нефтяной отраслей промышленности; Белорусский национальный технический университет, г. Минск, Беларусь, shvabia@tut.by
\end{abstract}

Abstract. The main vectors of social and economic progress of Belarus in the medium term are considered to be: increasing the welfare of the population, reducing poverty on the basis of rapid financial and economic recovery and increasing the competitiveness of the state. They found their place in the program of socio-economic development of our country until 2020. To implement these tasks, we need the continuation of institutional reforms, implementation of top-priority national projects in healthcare, education, provide housing for the population and progress of the agricultural sector, creating a positive climate for investment, restructuring the economy, modernization of the industrial complex and the activation of innovative work that will ensure significant and sustained financial and economic growth. This will require the creation of an effective financial and economic system based on equal competition, reducing the interference of state bodies in the work of economic entities and increasing the competitiveness of people, government agencies and business.

Аннотация. Главными векторами социально-экономического прогресса Беларуси на среднесрочную перспективу считаются: увеличение благосостояния населения, сокращение бедности на базе быстрого финансово-экономического подъема и увеличения конкурентоспособности государства. Они нашли свое место в Программе социальноэкономического развития нашей страны до 2020 года. Для реализации данных задач нужно продолжение институциональных преобразований, реализацию приоритетных государственных проектов в сфере здравоохранения, образования, обеспечивания населения жильем и прогресса агропромышленного сектора, создание положительного климата для инвестиций, проведение структурной перестройки экономики, модернизацию промышленного комплекса и активизацию новаторской работы, которые смогут гарантировать существенные и устойчивые темпы финансово-экономического роста. Для этого потребуется создание действенной финансово-экономической системы, основанной на равной конкуренции, понижении вмешательства госорганов в работу хозяйствующих субъектов и увеличении конкурентоспособности человека, госструктур и бизнеса.

Keywords: socio-economic security; the government; society; enterprise; employee; threat; security; interests; Economics, analysis, system.

Ключевые слова: социально-экономическая защищенность; государство; общество; предприятие; работник; угроза; защищенность; интересы; экономика, анализ, система. 
Effective provision of social and economic security of the Republic of Belarus is impossible without the formation of an effective mechanism for this work. The following main components can be identified in the mechanism of ensuring the socio-economic security of Belarus:

1) monitoring of the economy and society in order to identify and predict the internal and external dangers of socio-economic security;

2) development of threshold, maximum permitted values of socio-economic characteristics, the violation of which leads to instability and social incidents $[1 ; 2]$;

3 ) the activities of the country to identify and prevent the dangers of socio-economic security, which are characterized by:

differences in the public interest, the focus on the absolute allocation of their combined interests, not paying attention to the development of integration processes. Specificnost interests requires defining the methods for their implementation and development of the required strategy.

aggravation of the financial and economic struggle for the possession of resources due to the lack of natural resources, varying degrees of security of individual States.

the growing weight of the competition factor in the production and marketing of products, especially in the field of financial and banking services. The ability to create the necessary circumstances for the development of the financial and banking segment and to debug its clear work is put in 1 row with the ability to introduce advanced industrial and agricultural technologies. That's why raising the competitiveness of the 1 -States is seen by others as a threat, a risk to the public interest [3, p. 206; 4, p. 188].

Here it should be noted the features of ensuring the socio - economic security of Belarus, the likely ability of the Belarusian economy:

in-1, the acceleration of the formation of the country's structures and methods of ensuring socio-economic security;

in-2, the change in the model of interaction with the international economy, complementing the exchange of other forms of cooperation-the interweaving of capital, scientific and technical cooperation, industrial integration on the basis of the advanced paradigm of relations;

$\mathrm{b}-3-\mathrm{x}$, increase of the state income in comparison with the caused scales of domestic production complex on the basis of growth of global turnover of resources and increase of its efficiency;

4th, increase of labor productivity and competitiveness of the Belarusian economy, increase of the role of global exchange as a factor of balance of financial and economic growth.

A significant place in the mechanism of ensuring socio-economic security is its forecast. In the essence of the functioning of the mechanism of ensuring socio-economic security of the Republic of Belarus can be laid readiness and probability to guarantee macroeconomic stability under the influence of various external economic manifestations and factors. A significant role can be played by accession to the WTO on extremely favorable conditions for the Belarusian economy.

The main vectors of social and economic progress of Belarus in the medium term are considered to be: increasing the welfare of the population, reducing poverty on the basis of rapid financial and economic recovery and increasing the competitiveness of the state [5, p. 159]. They found their place in the program of socio-economic development of our country until 2020.

To implement these tasks, we need the continuation of institutional reforms, implementation of top-priority national projects in healthcare, education, provide housing for the population and progress of the agricultural sector, creating a positive climate for investment, restructuring the 
economy, modernization of the industrial complex and the activation of innovative work that will ensure significant and sustained financial and economic growth.

This will require the creation of an effective financial and economic system based on equal competition, reducing the interference of state bodies in the work of economic entities and increasing the competitiveness of people, government agencies and business.

Effective socio-economic development of the Republic of Belarus is now hampered:

* lack of criteria and incentives for human capital progress;

* low competition and a large share of the non-market sector;

* uneven implementation of reforms in different regions;

* low rate of integration of the Belarusian economy into international financial and economic relations;

* weak diversification of the Belarusian economy, which forms a significant dependence on the global price environment for the main export goods;

* infrastructure limitations of financial and economic growth [6, p. 64].

The interference of the authorities in the work of economic entities remains superfluous and burdensome. One of the major obstacles to the financial and economic recovery in Belarus at the current stage is considered to be an underdeveloped institutional environment, including a low level of protection of private property rights. There are no effective mechanisms of public control over decision-making on the main vectors of socio-economic development.

The demographic situation in the country is characterized by a low birth rate, a significant mortality rate, inefficient implementation of migration potential, which does not correspond to the strategic objectives of the Republic of Belarus and creates a danger of socio-economic security of the country.

The decrease in the number of able-bodied population makes it impossible to guarantee the formation of highly qualified labor resources necessary for the development of material and mental potential of the Republic of Belarus, and contributes to the tightening of Belarus ' technological dependence on foreign countries. The dynamics of the configurations of the leading social groups is shown in Table.

In order to ensure the availability and increase the quality of educational, medical and social services, it will be necessary to modernize health care, education and the public sphere, aimed at ensuring compliance of state guarantees of medical care, standards of education, forms of social support with available financial resources.

The share of the non-market segment in certain sectors of the economy remains quite significant, and the opacity of natural monopolies continues to exist, which does not allow to form the market environment entirely.

The current period of development of the global economy is characterized by an increasing level of globalization. A significant role is played not only by the size of foreign trade turnover, but also participation in global financial and economic processes, the place of the Belarusian economy in the international "chains" of value added formation.

The Belarusian economy is characterized by a very low rate of export diversification, inefficient introduction of competitive advantages in the export of services and products of scienceintensive sectors of the economy.

It is necessary to change the structure of the Belarusian economy and reduce its dependence on foreign economic conditions, primarily on the situation of tariffs for fuel and raw materials.

Globalization of the international economy and industrial relations is carried out while maintaining the national-state form of organization of financial and economic systems. Belarusian 
entrepreneurship, having received direct access to global markets, in most cases meets not just with individual competing companies, but with state-monopolistic structures, which they are unable to resist alone.

Table.

LEADING PUBLIC GROUPS IN THE REPUBLIC OF BELARUS, 1990-2015

\begin{tabular}{|c|c|c|c|c|c|c|}
\hline Years & 1990 & 1995 & 2000 & 2005 & 2010 & $2015 /$ \\
\hline Social group & \multicolumn{6}{|c|}{ Thousand. people } \\
\hline Entire population & 10189 & 10210 & 10003 & 9698 & 9500 & 9481 \\
\hline Hired worker & 5151 & 4012 & 4117 & 3994 & 4018 & $3868 / /$ \\
\hline including managers & - & 278 & 346 & 399 & 396 & $395 / /$ \\
\hline in the field of public administration & - & - & - & - & - & $22 / /$ \\
\hline Pensioners & 2279 & 2532 & 2501 & 2445 & 2469 & $2560 /$ \\
\hline Students, & 332 & 320 & 432 & 537 & 611 & $492 /$ \\
\hline including full-time education & 223 & 226 & 285 & 305 & 338 & $281 /$ \\
\hline \multicolumn{7}{|l|}{ Entrepreneurs } \\
\hline SP & 28 & 172 & 158 & 178 & 232 & 249 \\
\hline \multirow[t]{2}{*}{ SMEs } & 12 & 36 & 28 & 33 & 84 & 112 \\
\hline & \multicolumn{6}{|c|}{$\%$} \\
\hline Entire population & 100 & 100 & 100 & 100 & 100 & 100 \\
\hline Hired worker & 50,6 & 39,3 & 41,2 & 41,2 & 42,3 & 40,8 \\
\hline including managers & - & 2,7 & 3,5 & 4,1 & 4,2 & $4,2 / /$ \\
\hline in the field of public administration & - & - & - & - & - & $0,2 / /$ \\
\hline Pensioners & 22,4 & 24,8 & 25,0 & 25,2 & 26,0 & 27,0 \\
\hline Students & 3,3 & 3,1 & 4,3 & 5,5 & 6,4 & 5,2 \\
\hline including full-time education & 2,2 & 2,2 & 2,9 & 3,1 & 3,6 & 3,0 \\
\hline Entrepreneurs & & & & & & \\
\hline SP & 0,3 & 1,7 & 1,6 & 1,8 & 2,4 & 2,6 \\
\hline SMEs & 0,1 & 0,3 & 0,3 & 0,3 & 0,9 & 1,2 \\
\hline
\end{tabular}

And with $\mathrm{t}$ o h $\mathrm{n}$ I K: developed by the author on the basis of the statistics Of the Republic of Belarus [7, 8] Note: / - data at the beginning of the year, / / - data for 2014, individual entrepreneurs, SMEs-small and medium-sized enterprises

The need to ensure the socio-economic security of Belarus requires the Belarusian economy to introduce innovative sectors of the economy. At the same time, globalization makes it particularly elastic and capable of quickly rebuilding its own financial and economic structure and increasing the quality of products in response to increased competition from classical and new foreign producers.

In a series of studies R. Hausmann and co-authors consider the impact of exports on the formation of the economies of fast-growing States. In particular, they studied the ability of export diversification.

Diversification of economies is rarely performed by the method of upward movement in vertical production chains. In other words, if the state produces fabrics, it is wrong to think that the logical direction of diversification for it will be the creation of clothing. In practice, fabrics and clothing are produced by different States.

Diversification of the economy takes place in the direction of the products that make similar requests to the resources and equipment used, the human factor and the institutional environment. That is, if the state is engaged in the production of computers, it has the opportunity to master the creation of laptops, and in the future - and cellular telephones. 
Applying the data on the commodity structure of the world's exports, R. Hausman and B. Klinger derived a measure of the distance between the products. It is calculated as the inverse of the probability that a state exports 1 product, provided that it exports another.

The study of the field of this product allows us to note a number of large commodity agglomerations, within which the products are close to each other and, thus, the diversification from the 1 st product to the 2 nd has the ability to occur relatively simply. These are groups of electrical products, fabrics, clothing, and products of classical industrial sectors of the economy. Other products are at a relatively far distance from each other, and a simple way to diversify the economy, specializing in the export, will not be easy. Natural resources and agricultural products occupy an important place among these segments [9].

The success of Asian countries in the last 40 years is due to the fact that they have managed to find their own specialization in a fairly dense cluster of electrical products in terms of the distance between the products and then simply expand it.

The group managed By R. Hausmann calculated the distances between the products of export specialization of our closest ally - Russia. The results of the calculations were similar [10].

Russian exports are located on the periphery of the product field, and the distances to the nearest products from the existing export basket are quite large. In consequence of this estestvena or "organic", diversification of the Russian economy is very complicated [11, p. 105]. It is possible to imagine that the Belarusian economy is in a similar situation.

With the established structure of the economy, it is necessary to find mechanisms and tools to stimulate investment in the creation of not only similar products, but also located in those agglomerations, where it is possible to simply implement "organic" diversification. Similar investments involve significant risk because it is not clear whether they will become commercially profitable.

Now the state bodies that support the elasticity of the financial and economic structure of Belarus and stimulate experimentation (of course, aimed at increasing productivity) on the part of both business and the country in the field of structures that support business.

From the written it follows that for the diversification of the economy, which has a structure close to the Belarusian one, two types of structures are needed: state structures that stimulate investment in promising areas, and business and state structures that ensure the work of economic entities in promising sectors in the Belarusian and international markets.

At the same time, the structure of the bodies of the 2nd type significantly depends on the specialization that will develop in Belarus. However, it is possible to note some main features, joint for 2 types of structures. These include:

- stimulation of innovations and investments in innovative spheres of work for the state, which is associated with a significant risk;

- the presence of structures to reduce the information difficulties that arise in business when entering into innovative areas of work or in the process of work in them (examples: consulting services, benchmarking, legal services, etc.);

- developed systems of protection of contracts and property rights, ensuring the protection of the interests of the parties, including in the criteria of significant uncertainty and significant risks;

- availability of methods of financing risk projects, that is, the division of risks between different groups of investors;

- creation of a system of training and retraining of employees and the formation of competencies that can be quickly restructured to meet the needs of innovative areas of activity. 


\section{References:}

1. Shvaiba, D. (2019). Dynamic regression models of forecasting indicators of social and economic security. Bulletin of Science and Practice, 5(1), 249-257.

2. Shvaiba, D. (2018). The content of the forecast of socio-economic security of the industrial sector of the Republic of Belarus. Bulletin of Science and Practice, 4(8), 177-182.

3. Tatuev, A. A. (2015). Vzaimosvyaz' sotsial'no-ekonomicheskogo razvitiya territorii s ekonomicheskoi bezopasnost'yu Rossii. Ekonomika i predprinimatel'stvo, (6/1). 205-208.

4. Yalmaev, R. A., \& Magomadova, M. S. (2016). Ekonomicheskaya bezopasnost' regionov kak faktor ikh ustoichivogo sotsial'no-ekonomicheskogo razvitiya. Science, (2). 187-189.

5. Mezentsev, M. M. (2014). Natsional'naya bezopasnost' Belarusi v sotsial'noi sfere. Sb. nauch. st. Minsk. (26). 158-166.

6. Mikhailov, L. M. (2007). Sotsial'no-ekonomicheskoe razvitie Rossii v srednesrochnoi i dolgosrochnoi perspektive: analiz sovremennykh programm i kontseptsii. In Sbornik nauchnykh trudov prepodavatelei MAEP. Moscow. MAEP, 62-69.

7. Respublika Belarus' = Republic of Belarus: stat. ezhegodnik, 2015. (2015). Minsk: Nats. stat. kom. Resp. Belarus'. 524.

8. Trud i zanyatost' v Respublike Belarus', 2009-2013. (2014). Minsk. 320.

9. Hausmann, R., \& Klinger, B. (2007). The structure of the product space and the evolution of comparative advantage. Cambridge: Center for Intern. Development at Harvard Univ., 16.

10. Hausmann, R., Hwang, J., \& Rodrik, D. (2007). What you export matters. J. of Econ. Growth, 12(1). 1-25.

11. Lipatova, L. N., Gradusova, V. N., \& Modin, E. V. (2016). Regional'naya differentsiatsiya sotsial'no-ekonomicheskogo razvitiya kak ugroza ekonomicheskoi bezopasnosti. Upravlen. konsul'tirovanie, (5). 102-111.

\section{Список литературы:}

1. Shvaiba D. Dynamic regression models of forecasting indicators of social and economic security // Бюллетень науки и практики. 2019. Т. 5. №1. С. 249-257.

2. Shvaiba D. The content of the forecast of socio-economic security of the industrial sector of the Republic of Belarus // Бюллетень науки и практики. 2018. Т. 4. №8. С. 177-182.

3. Татуев А. А. Взаимосвязь социально-экономического развития территорий с экономической безопасностью России // Экономика и предпринимательство. 2015. № 6/1. С. 205-208.

4. Ялмаев Р. А., Магомадова М. С. Экономическая безопасность регионов как фактор их устойчивого социально-экономического развития // Science. 2016. № 2. C. 187-189.

5. Мезенцев М. М. Национальная безопасность Беларуси в социальной сфере // Сб. науч. ст. Минск. 2014. Вып. 26. С. 158-166.

6. Михайлов Л. М. Социально-экономическое развитие России в среднесрочной и долгосрочной перспективе: анализ современных программ и концепций // Сборник научных трудов преподавателей МАЭП. М.: МАЭП, 2007. С. 62-69.

7. Республика Беларусь = Republic of Belarus: стат. ежегодник, 2015. Минск: Нац. стат. ком. Респ. Беларусь. 2015. 524 с.

8. Труд и занятость в Республике Беларусь, 2009-2013. Минск. 2014. 320 с.

9. Hausmann R., Klinger B. The structure of the product space and the evolution of comparative advantage. Cambridge: Center for Intern. Development at Harvard Univ., 2007. 16 p.

10. Hausmann R., Hwang J., Rodrik D. What you export matters // J. of Econ. Growth. 2007. Vol. 12, № 1. P. 1-25. 
11. Липатова Л. Н., Градусова В. Н., Модин Е. В. Региональная дифференциация социально-экономического развития как угроза экономической безопасности // Управлен. консультирование. 2016. № 5. С. 102-111.

Работа поступила в редакцию 16.05.2019 2.
Принята к публикациии 21.05.2019 2.

Ссылка для циитирования:

Shvaiba D. Formation of the Social and Economic Security Mechanism of the Republic of Belarus // Бюллетень науки и практики. 2019. Т. 5. №6. С. 336-342. https://doi.org/10.33619/2414-2948/43/44

Cite as (APA):

Shvaiba, D. (2019). Formation of the Social and Economic Security Mechanism of the Republic of Belarus. Bulletin of Science and Practice, 5(6), 336-342. https://doi.org/10.33619/2414$2948 / 43 / 44$ 